\title{
A Three Step Approach Analysis of the Portrayal of Images of Women in three Ghanaian Newspapers: Newsone, Ebony and The Mirror
}

\author{
By Henry Kojo Bonsu-Owu*
}

\begin{abstract}
Media portrayal of women in traditional stereotypical roles such as mothers, or seductresses has been the norm for years. However, the changing socioeconomic and political environment and advancement of women in today's society have given rise to questions on the appropriate portrayal of women in the media today. The purpose of the study is to analyze the portrayal of women in Ghanaian newspapers and find women's perception on the issue. The study uses a three step approach in gathering data for analysis. Using the stratified sampling method it analyzes front page images of women from 210 issues of the selected newspapers. Further, it administers questionnaires to 100 female students to find out how they relate to the images of women in the selected newspapers. Finally, editors of the newspapers are interviewed to find their rational for portraying women as seen on their front pages. The findings suggest that the newspapers portray women for varied reasons such as promoting sales and influencing the public agenda. Further, the female students claim that in spite of women's vast contribution to the growth of society, the media continue to marginalize them. They add that such portrayals promote and reinforce social construct, however they refuse to see themselves through the male gaze concept. The study concludes that the stereotyped portrayal of women is likely to continue if the government, regulatory bodies, the media and society do not make a conscious effort to address this problem.
\end{abstract}

Keywords: newspaper, portrayal, social construct, women.

\section{Introduction}

In Ghana, the media have played no mean role in the country's socio-political development. However, in spite of women's vast contributions to the national growth, the media seemingly continue to marginalize women. The social construction of women in stereotypical roles such as mother, helpmate, or seductress goes beyond how the public sees them to firming and institutionalizing such beliefs. Ghana's liberal media landscape however presents a new challenge for the media given rise to questions on the appropriate portrayal of women in the media.

\section{Background of the Study}

According to The Women's Manifesto for Ghana (2004) a liberalised media environment such as pertains in Ghana, with its commercial pressures, is bound to produce news and programmes that do not empower women or promote gender equity adding that the underlying commercial interests that govern the media worldwide and perpetuate the axiom that "sex sells" are responsible for some of the common problems of women's representation (p. 50).

*Lecturer, Faculty of Journalism, Head of Department, Print Journalism, Ghana Institute of Journalism, Ghana. 
Treise, Weigold, Conna and Garrison (1994) add that the media fail to echo the changing roles of women and rather focus on them as sex objects, "happy homemakers"; incompetent, inferior and as subordinates to men. Therefore, not only are women underrepresented by the mass media, but they are also depicted unrealistically (p. 61).

Olorunpomi (2011) adds that

...it is quite offensive for (the media) to put such pictures on the pages of a newspaper, bearing in mind that we have not only an adult audience but also a youth audience. It goes to show we need to start monitoring what comes out of the media (para. 4).

\section{Problem Statement}

The level of social, economic, political and academic achievements of women in the 21 st century seem to suggest they would no longer be limited by their gender or steered into traditional roles (Paynter, 2011). However, studies by Anderson and Hamilton (2005), Diekman and Murnen (2004), Gooden and Gooden (2001), as cited in Paynter (2011) show that the media continue to portray images which stereotype women negatively.

Furthermore, studies by Blaha (2009), Cronn-Mills (2009), Ranchod (2007) which focused on the representation of women in magazine advertisements recommend further studies in a range of print media sources including newspapers so as to present a wider picture of the portrayal of women in the print media.

Though there exist lots of studies on newspaper portrayal of women (Olorunpomi, 2011; Jooste, 2007; Nwagbara, 2006; Potter, 1985) works cited within the Ghanaian context (Zaney, 2012; Quainoo, 2011; Zwennes, 1996; Mensa-Bonsu, 1992) tend to focus on state-owned newspapers such as the Daily Graphic, Ghanaian Times, Spectator and The Mirror. This study thus seeks to bridge the gap by analyzing the media's portrayal of women from three angles, firstly from the perspective of both private and state-owned newspapers. Additionally, it addresses the issue from the perspective of women themselves as most of the previous studies (Kang, 1997; Goffman, 1978) tend to look at the issue from the perspective of the male gaze, and finally from the perspective of editors of the newspapers.

\section{Objective of the Study}

The study's main objective is to analyze the portrayal of women in Ghanaian newspapers. The specific objectives of the study are as follows:

1. To explore how women are portrayed in the print media.

2. To investigate how women relate to the images of women as portrayed by the print media.

3. To find the rational for the portrayal of women in the newspapers. 


\section{Research Questions}

1. How are women portrayed in the print media?

2. How do women relate to the images of women as portrayed by the print media?

3. What is the rational for the portrayal of women in the print media?

\section{Significance of the Study}

The ability of the print media to inform and influence our basic thoughts, persuade and shape our beliefs gives it power over society (Thurm, 2001). It is therefore significant to look at the issue of the portrayal of women in newspapers as it will help shape society and indicate the importance of women in society. The study also provides insights into how women themselves react to such images that represent the diverse roles of the contemporary women.

Socially the study aims at creating consciousness of the place of the $21 \mathrm{st}$ century woman in nation building, and communicate to the public that the contemporary woman has gone beyond the traditional stereotype of being a home keeper or sex object for sale to become assertive and development minded and that they can be as resourceful and intelligent as any man.

\section{Scope of the Study}

The study is limited to images (pictures) from the front pages of two private owned Ghanaian newspapers Newsone and Ebony and a national weekly newspaper The Mirror over a five year period 2012-2017. The study also questions the rational for the portrayal of women in the print media from the viewpoint of the editors of the newspapers and how women also see such portrayals.

\section{Literature Review}

The review is categorized under the following sub-headings: The role of the media, Media and portrayal of women, Portrayal of women by newspapers, Stereotyping women in the print media, Women empowerment and Feminists' perception.

\section{The Role of the Media}

In an age of information and technological advancement the role of the media has gone far beyond the supply of information to giving them the power to create reality. Therefore by gradually shaping public opinion, personal beliefs and even people's self-perceptions, media influences the process of socialization and shapes ideology and thinking (Chopra, 2008). One such 
important media is the newspaper which continues to play a very significant role in the development of many countries the world over (Quainoo, 2011).

As gatekeepers of information, the media to a large extent regulate what we see and know by deciding what programmes to air, what news stories to feature, what images to show and how to represent people, issues and events (Woods 1994, as cited in Hammond, 1999).

\section{Stereotyping Women in the Print Media}

According to Abbam (1975), as cited in Gallagher (n.d., p. 15), the newspaper "has become more commercial and lively, partly through the use of women on its covers as sales bait". Quainoo (2011) adds that the Editorial Board of The Mirror over a decade ago adopted reader-oriented measures, one of it being the use of pretty faces of women on its cover pages to attract readership because of the perception that women are more attractive to readers.

Wella, Burnett and Moriarty (1992) define stereotyping as "presenting a group of people in an unvarying pattern that lacks individuality and often reflects popular misconceptions" (as cited in Nwagbara, 2006, p. 21).

Goffman (1978), as cited in Kang (1997), mentions that women are portrayed as weak via five categories, Relative Size (women shown smaller or lower, relative to men), Feminine Touch (women constantly touching themselves), Function Ranking (occupational), Ritualization of Subordination (proclivity for lying down at inappropriate times, etc.), and Licensed Withdrawal (women never quite a part of the scene, possibly via far-off gazes).

Kang (1997) introduces two more categories, Body Display as well as Independence and Self-Assertiveness. He states under Body Display that occasionally magazine advertisements show little pigeonholing of women in terms of relative size, feminine touch, function ranking, ritualization of subordination, and licensed withdrawal, the female models on the other hand show high degree of nudity which is another important way of stereotyping.

\section{Reducing Stereotype Roles of Women}

According to Nwagbara (2006), the call for a reversal in the stereotyping of women "would not have been necessary were stereotypes not dangerous. They are usually built on half-truths, distortions, sometimes untrue premises and this is made worse by the fact that stereotypes are resistant to change" (p. 24). Thus one can only imagine the effect such continuous exposure of the public to this kind of information will have on them. "In that circumstance, people will very easily come to accept lie for fact and myth for reality" (Nwagbara, 2006, p. 24).

Baldwin (1999), as cited in Thurm (2001), exploring sexualized imagery as power in advertising, focus on semiotic signifiers and how advertising and programming provide some of the social cues in the construction of Self ${ }^{1}$. Thurm (2001, p. 15) further mentions that "girls negotiate and construct their own

\footnotetext{
${ }^{1}$ Herbert Blumer theorizes that the Self exists because the individual can respond to himself as an object. It is one of Blumer's three cardinal concepts (Society, Self and Mind).
} 
gendered identities through different definitions of what it means to be a woman from the media", and Nwagbara (2006, p. 24) mentions that "herein in lies the real danger in stereotyping".

Some studies however indicate a gradual change in the stereotypical roles of women. Nwagbara (2006) adds that African women can be as intellectually capable as men if given the opportunity. Some of them serve as chief executives of large conglomerates, some hold sensitive political positions, a lot of them work outside the home, others are established business magnates while others are involved in varied lucrative ventures.

\section{Feminist Perspective}

Paglia (1992), as cited in Zimmerman and Dahlberg (2008, p. 72), notes that:

Third wave feminists now stress a new feminism; one that is not stiff and oldfashioned, but bold, fun, and in line with popular culture. This feminism embraces sexuality. It views sex as power. It separates women from men and sees women as the dominant sex.

Obenewaa (2007) also contends that a woman's right to respect, and equal treatment, and to be seen as a useful member of society has nothing to do with her sexual orientation. She adds that Ghanaian women are capable actors, and can demand equal rights from the state without giving in to the impositions of society's patriarchs.

\section{Methodology}

This research is based on an analysis of only photographs of women appearing on the front pages of two Ghanaian privately owned newspapers, Newsone and Ebony, and a state-owned weekly, The Mirror. It should therefore be noted that all other texts such as banner headlines, captions and copy text were not considered in this study. The sampling frame selected for this study was over a five year period from 2012 to 2017.

The study referred to categories used by previous researchers such as Blaha (2009), Cronn-Mills (2009), Ranchod (2007), and Kang (1997).

\section{Research Approach}

The study employed the mixed method approach to enhance its credibility. Furthermore, to increase the reliability of its findings the study employed triangulation ${ }^{2}$. Images of women on the front pages of the three newspapers are

\footnotetext{
${ }^{2}$ Triangulation in qualitative research has come to mean a multimethod approach to data collection and data analysis. The basic idea underpinning the concept of triangulation is that the phenomena under study can be understood best when approached with a variety or a combination of research methods. Triangulation is most commonly used in data collection and analysis techniques, but it also applies to sources of data (Given, 2008, p. 892).
} 
analyzed and interpreted bringing out the most recurring categories and themes as portrayed by the three newspapers. Additionally, editors of two of the three newspapers, Newsone and The Mirror, were interviewed and the interviews transcribed, the approach to the interviews was unstructured; to make room for the interviewees' own perspectives on the issue at stake. Additionally the study used tables and figures in presenting the findings of the coders and that of survey questions posed randomly to female students of the Ghana Institute of Journalism to find out how they relate to the images of women as portrayed in the selected newspapers. It must however be noted that the tables and figures in this study were not subjected to strict quantitative statistical analysis but were used to generate frequencies and percentages which aided in the analysis of data.

\section{Research Design}

The research employed a five step procedure from the book, Investigating Communication: An Introduction to Research Methods (Frey, Botan, Friedman \& Kreps, 1991, as cited in Cronn-Mills, 2009). The step by step procedure includes: Selecting texts, determining the unit of analysis, developing content categories, coding units and analyzing the data.

\section{Selecting Text}

A purposive sampling method was used to select the sample. Since the focus of the study was to examine the portrayal of women in newspapers, Paradigmatic Case Sampling ${ }^{3}$ one of the several methods of purposive sampling as cited by Given (2008) in the Sage Encyclopedia (p. 697) was used in selecting Newsone and Ebony newspapers since the two newspapers seemingly mirror the portrayal of women as sex objects. Additionally, The Mirror newspaper, a national weekly, was purposively selected since it gives the greatest coverage on women based issues as compared to other state-owned newspapers such as The Daily Graphic and The Ghanaian Times (Asamoah, 1980). Moreover, Hammond (1999) mentions that weeklies have been generally known to cover more of stories about women.

\section{Sample Size}

In selecting the sample size Riffe, Lacy and Fico (1998), as cited in Pedersen (2002), indicate that "the most efficient stratified sampling method for inferring to a year's content for newspapers is to sample two constructed weeks from the year" (p. 307). Accordingly, two constructed weeks constituting 14 issues per newspaper were randomly chosen as the sample from each of the 3 newspapers. The total sample size for this study was 210 issues, consisting of 42 issues from each newspaper, that is, one issue per month in a

${ }^{3}$ Paradigmatic Case Sampling: A case is paradigmatic when it is considered the exemplar for a certain class (Given, 2008, p. 697). 
given year and two additional issues from any month within the same year (Stemple, 1952, as cited in Riffe, Lacy and Fico, 1998).

As mentioned, text for the study was selected from 210 issues of the three newspapers over a five year period (2012-2017) which works out as follows:

1. 1 Newsone newspaper +1 Ebony newspaper +1 Mirror newspaper $=3$ newspapers per month $\mathrm{x} 12$ months $=36$ newspapers per year.

2. 36 newspapers +6 ( 2 additional issues per paper from any month $)=42$ newspapers.

3. 42 newspapers $x 5$ years $=210$ newspapers.

According to Enu-Kwesi (2006) this process saves time and is likely to produce an unbiased sample.

\section{Determining the Unit of Analysis}

"A unit of analysis is the smallest element or indicator of the phenomenon of interest in a content analysis"4 (Kimani 2009, p. 66). Wimmer and Dominick (2003), as cited in Kimani (2009), note that unit of analysis "might be a single word or symbol, a theme or an entire article or story" (p. 66). The broad unit of analysis for this study consisted of only images of women as presented on the front pages of the three newspapers. Where a front page carried more than one picture of a woman or women the picture which covered more space in terms of size was analyzed for the study. Text and images of men were not considered in this study. The three major themes ${ }^{5}$ identified for this study are Facial Expression, Body Language and Clothing. At least one of the three themes was present in each of the newspapers. The recurring display of these themes within the selected unit of analysis, gave grounds to conducting an appropriate content analysis.

\section{Developing Content Categories}

Having identified the three major themes there was the need to place them within the most evident and prevalent content categories (Cronn-Mills, 2009). The categories were based on the kind or level of exposure of female sexuality on the front pages of the selected newspapers. The most reoccurring issues in line with Blaha's (2009) study were chosen as my six categories:

1. Facial Expression.

2. Body Language.

4. Percentage of Coverage.

5. Camera Angle.

\footnotetext{
${ }^{4}$ According to Reinard (2008, p. 302), as cited in Cronn-Mills (2009), content analysis is a research technique which is applied in defining and systematically analyzing the content of transcribed, verbal, or pictorial communication.

${ }^{5}$ Frey et al. (1991) as cited in Cronn-Mills (2009) indicate that thematic units are the issues enclosed within messages.
} 
6. Degree of Clothing.

7. Type of Clothing.

Additionally, subcategories ${ }^{6}$ were identified within each of the above categories.

\section{Coding Units}

Wimmer and Dominick (2003), as cited in Kimani (2009), note that "placing a unit of analysis into a content category is called coding" (p. 67). Charmaz (1983, p. 111), as cited in Lindlof and Taylor (2002, p. 216), adds that "Codes...serve as shorthand devices to label, separate, compile and organize data". To indicate the core purpose of coding, Lindlof and Taylor (2002) note that "...coding is to mark the units of text as they relate meaningfully to categories (concepts, themes, constructs)" (p. 216). Additionally, Baran (1999, p. 352), as cited in Pawlowski (2007), describes a coding schedule as an instrument that allows a "valid and reliable category scheme to count the number of times a piece of content fits each category" (p. 41).

The coding system designed for this study looked at the diverse aspects of how female sexuality is portrayed by the three newspapers. The categories that were coded in accordance with Blaha (2009) include percentage of coverage, facial expression, body language, degree of clothing, type of clothing. The following subcategories were indicated within each of the categories:

\section{Facial expression subcategories}

Neutral: when the woman has no expression.

Smiling: when the woman has an open mouthed smile with teeth, or closed mouth smile.

Seductive: placing a finger or object in or near her mouth, blowing a kiss, red hot wet lips, sleepy sexy eyes or running her tongue over her lips.

Other: an expression of the woman that does not fit the above categories. $N / A$ : when the expression of the woman is not visible.

\section{Body language subcategories}

Courteous: when the woman is not flaunting her body in a sexual way.

Dominant: when the audience gets the feeling that the woman has power or authority by the way she is standing or the way her body is positioned near an object.

Submissive: when the woman is portrayed as a wife or mother. Or does not appear confident (head is down, shoulders were rounded down).

Sexual: when majority of skin is shown or the body language implies sex by placement of hands and pose of body (e.g. when the woman is in a sexual pose like sitting with her legs wide open).

Other: a pose that does not fit in the above categories.

\footnotetext{
${ }^{6}$ Subcategories as described under Coding Units.
} 
3. Percent of coverage subcategories

Full Page: means the woman's image is more than $50 \%$ of the whole cover page.

Half Page: when the woman's image covers at least $50 \%$ of the page.

Quarter Page: when the woman's image covers $25 \%$ of the page

Less than Quarter Page: when the woman's face covers less than $25 \%$ of the page.

4. Camera angle subcategories

90 degrees: when the woman is looking right into the camera.

45 degrees: when the woman's face is showing sideways

Away from camera: when the woman's gaze is away from the camera.

Gaze Not Visible: the woman's gaze was not visible, e.g. in sunglasses and head is at an angle other than 90 degrees.

\section{Type of clothing subcategories}

Casual: clothing suitable for wearing on informal occasions, e.g. jeans, mini skirt, t-shirt or blouse.

Formal: clothes suitable for an important occasion, office or meetings, e.g. a full-length dress or suit.

Lingerie: underwear, nightgown or bathrobe, a one piece or two-piece swimsuit, or bikini.

Traditional: clothing deemed to be Ghanaian or African, e.g. Kente, Kaba and Slit.

Other: where image as shown does not fit the above categories.

6. Degree of clothing subcategories

Nude: woman with no clothing on.

Seminude: woman dressed with very little clothing (e.g. bikini or just a wrapper round her waist) with a greater part of her body such as breast/upper body, buttocks, crotch, and legs showing.

Fully dressed: woman whose dress covers most of her sensitive parts such as breast, buttocks, midsection and thighs.

Other: where image as shown does not fit the above categories.

Body part shown: breast/cleavage, buttocks, genitals, legs (thighs and calves) and midsection (between chest and waist).

\section{Reliability and Validity}

"To avoid measurement errors and to ensure reliability and accuracy of the findings" (Du Plooy, 2002, as cited in Ranchod, 2007, p. 33) pretesting of the coding instrument was undertaken to work out any coding problems. For pretesting, sample questionnaires were tested on 20 female students of the Ghana institute of Journalism. Additionally, 48 issues of the three newspapers were randomly picked. Of this number two coders were given the same set of 20 randomly picked issues. The pre-testing helped clarify the "coding categories, 
instructions, key terms, and definitions and provided familiarity with the coding process" Ranchod (2007, p. 33).

Johnson and Christensen (2008) mention that by testing for inter coder reliability a researcher is able to moderate the level of subjectivity and also decrease errors that may result from the varying backgrounds or experiences of the coders. A composite reliability coefficient was therefore computed using Holsti's (1969) technique, as cited in Tsegah (2009) and Kang (1997). The coefficient as per Holsti's formula is calculated as follows:

$$
\text { Percentage of agreement }=\frac{\text { Agreement }}{\text { Agreement }+ \text { Disagreement }}
$$

or $P A o=\frac{2 A}{n 1+n 2}$ where $P A_{\mathrm{o}}$ is the proportion agreement observed, $A$ is the number of agreements between two coders, $n_{1}, n_{2}$ are the respective number of items coded by each of two coders (Neuendorf, 2002).

According to Holsti (1969), as cited in Tsegah (2009), " $\mathrm{p}_{\mathrm{i}}$ is always greater than zero and less than one, where zero indicates a perfect disagreement, and one indicates a perfect agreement" (p. 68). The inter-coder agreement for the pretesting was $0.85(17 /(17+3)=0.85)$ which indicated an agreement among the coders.

For the main study, two coders were asked to independently examine the same set of 42 randomly picked newspapers (14 issues of each newspaper) representing $20 \%$ of the total sample size. The coefficient was calculated as follows:

$$
\frac{38 \text { agreements }}{38 \text { agreements }+4 \text { disagreements }}=0.90
$$

indicating a $\mathrm{p}_{\mathrm{i}}$ greater than zero and less than one thus an agreement among coders.

\section{Analyzing the Data}

Guided by previous studies such as Blaha (2009), Tsegah (2009), Kimani (2009), and Pedersen (2002) a coding sheet was designed to document the frequency of units in each category. Additionally three coders ${ }^{7}$ (Level 400 students of Ghana Institute of Journalism (GIJ) operating independently of each other were chosen and briefed by the researcher about the various subcategories they were going to use in conducting the coding which according to Tsegah (2009) would help the coders acquaint with the demands of the study and afford both the researcher and coders the chance of reducing any misconceptions. The coders were guided by a coding system provided by the researcher adopted from Blaha's (2009) study.

\footnotetext{
${ }^{7}$ According to Babbie (2004), as cited in Ranchod (2007), a coder is "someone, trained by the researcher, to locate the variables and interpret the codes" (p. 33).
} 
After an inter coder reliability of 0.90 based on $20 \%$ of the total sample size was established, the remaining $80 \%$ representing 168 newspapers were randomly divided between and coded by all three coders. Responses generated by the coders were processed and presented by the researcher in tabular form using Microsoft Excel \& Word software for easy interpretation and analysis.

A second step was to transcribe the interviews granted the editors of the newspapers. This was achieved by repeatedly playing back the recorded interviews and then transcribing the text which aided in revealing recurring themes, each theme was given a marker descriptive of its content and this was reviewed several times in an effort to reduce the researchers own interpretations upon the findings.

Finally, questionnaires were administered to a total of 100 female students of the Ghana Institute of Journalism. Their responses to the survey questionnaires were analyzed and presented in tabular and bar chart form.

\section{Population}

The population for this study comprised three newspapers Newsone, Ebony and The Mirror over a five year period (2012-2017) with only images of women from the front pages of the three newspapers serving as units of analysis; editors of the selected newspapers and female students of the Ghana Institute of Journalism. The population was sampled purposively to aid in answering questions raised by the study and its objectives.

\section{Distribution of Respondents by Programme and Area of Specialization}

All 60 respondents selected to answer the questionnaire were female students from the Ghana Institute of Journalism. In order to get a wider frame of responses the study chose 20 Regular Level 300 students, 20 Regular Level 400 students and 20 weekend Top-Up Level 400 students. For each group of 20, the study further expanded the scope of respondents by area of specialization thereby picking 10 students of Public Relations and 10 students of Journalism from each level.

\section{Research Instruments}

The research instruments used in this study include interviews, questionnaires and newspapers. The interviews were unstructured which according to Given (2008) makes room for the interviewees' own perspectives on the issue at stake. The questionnaires on the other hand employed both open and close ended questions. Given (2008) notes that closed ended questions are posed by researchers to participants in research projects that specify the parameters within which participants can frame their answers whiles opened ended questions are designed to give participants freedom to initiate topics within research settings (p. 83). The newspapers were selected purposively to enable the researcher gather enough data for content analysis. 


\section{Data Analysis Technique}

The data gathered were analyzed using the following techniques:

Firstly the recorded interviews were transcribed to bring out the most recurring themes, secondly the survey questions were analyzed in tabular form (frequency and percentage) using Microsoft Excel \& Word software, and finally content analysis of the selected newspapers were categorized, coded and presented in tabular form using Microsoft Excel \& Word software.

\section{Setting for Interviews}

In order to guarantee privacy and confidentiality interviews were conducted at the offices of the respective editors on an appointment basis at mutually convenient times. The locations were chosen on the assumption that they would provide a setting not only conducive to further disclosure but also appropriate should any of the interviewees need further sources of reference.

\section{Findings and Analysis}

\section{How are Women Portrayed in the Newspapers?}

The findings are based on three major themes identified (Facial expression, Body language and Clothing) and further analyzed under six categories (Facial expression, Body language, Percentage of coverage, Camera angle, Degree of clothing and Type of clothing) as per Blaha's (2009) study.

\section{Facial Expression Subcategories}

This category reveals how the selected newspapers portray the characteristics of women through their facial expressions, looking at the perceptual impressions they leave on the minds of readers and the general concept these images tend to invoke. Facial Expression was divided into five subcategories Neutral (woman has no expression on her face), Smiling (woman has an open or closed mouth smile), Seductive (placing a finger or object in or near her mouth, blowing a kiss, red hot wet lips, sleepy sexy eyes or running her tongue over her lips), Other (expression is visible but does not fit the above categories) and Not Applicable (expression of the woman is not visible).

As shown in Table 1, the Smiling and Seductive subcategories returned the most scores. Under the Smiling subcategory The Mirror newspaper returned the highest score of $83.93 \%$. Of all the three newspapers the Ebony had the most tendency of portraying sexualized images of women (Seductive, 78.57\%) under the category of facial expression. Blaha (2009) submits that the print media portrays sexualized images of women on the basis that $75 \%$ of women were seen to have seductive facial expressions as against $20 \%$ just smiling. The total results of the facial expression category for this study portrays a different picture with 
$51.79 \%$ of the women depicted as just smiling, while $40.48 \%$ were depicted as seductive thus suggesting a decrease in the use of facial expression to portray sexualized images of women by the Ghanaian newspapers.

Table 1. Frequency and Percentages of Facial Expression Subcategories per Newspaper

\begin{tabular}{|l|c|c|c|c|c|c|c|c|}
\hline Subcategory & \multicolumn{2}{|c|}{ Newsone } & \multicolumn{2}{c|}{ Ebony } & \multicolumn{2}{c|}{ The Mirror } & \multicolumn{2}{c|}{ Total } \\
\hline & Freq. & $\%$ & Freq. & $\%$ & Freq. & $\%$ & Freq. & $\%$ \\
\hline Neutral & 2 & 3.57 & 1 & 1.79 & 6 & 10.71 & $\mathbf{9}$ & $\mathbf{5 . 3 6}$ \\
\hline Smiling & 30 & 53.57 & 10 & 17.85 & 47 & 83.93 & $\mathbf{8 7}$ & $\mathbf{5 1 . 7 9}$ \\
\hline Seductive & 22 & 39.28 & 44 & 78.57 & 2 & 3.57 & $\mathbf{6 8}$ & $\mathbf{4 0 . 4 8}$ \\
\hline Other & 1 & 1.79 & 1 & 1.79 & 1 & 1.79 & $\mathbf{3}$ & $\mathbf{1 . 7 9}$ \\
\hline N/A & 1 & 1.79 & 0 & 0.00 & 0 & 0.00 & $\mathbf{1}$ & $\mathbf{0 . 5 9}$ \\
\hline Total & $\mathbf{5 6}$ & $\mathbf{1 0 0 . 0 0}$ & $\mathbf{5 6}$ & $\mathbf{1 0 0 . 0 0}$ & $\mathbf{5 6}$ & $\mathbf{1 0 0 . 0 0}$ & $\mathbf{1 6 8}$ & $\mathbf{1 0 0 . 0 0}$ \\
\hline
\end{tabular}

Source: Sampled newspapers, 2018.

Notwithstanding, all three newspapers were found to use facial expression as a sign in defining the Ghanaian woman. For example in Figure 1, Newsone carries a sexually suggestive image of Afia a popular Ghanaian songstress suggestively running her tongue over her lips, the Ebony carries the image of a model with sleepy sexy suggestive eyes while The Mirror has an image of Ghanaian actress Lydia Forson also portraying sexy suggestive eyes coupled with a Mona Lisa smile. These images buttress Ranchod's (2007) assertion that "women in visual images connote 'to-be-looked-at-ness', to play the role of being desirable" (p. 23).

\section{Figure 1. Sample Images of Newspaper Coded under Facial Expression Category}

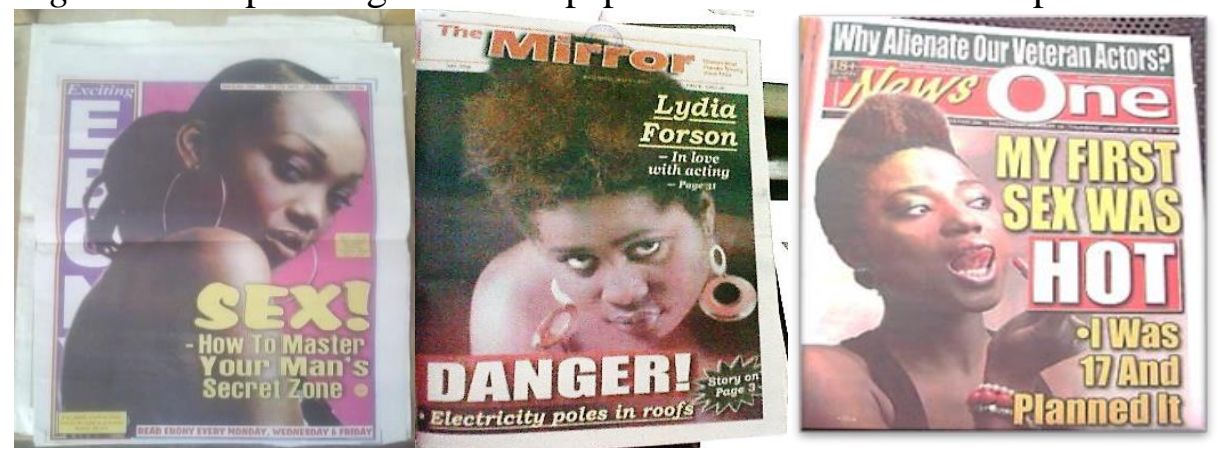

Source: Sampled newspapers, 2018.

From another angle these images tend to portray female icons like Afia and Lydia Forson as divas 9 supporting Thurm's (2001) assertion that "the stereotypic character traits attributed to women have shifted from weak and dependent to strong and autonomous" (p. 3). The bold statement made by the portrayal of such images tend to back Zimmerman and Dahlberg's (2008) contention that the new wave of feminists now push a new agenda for feminism; one that is not rigid or

\footnotetext{
${ }^{8}$ A 14 th century painting by Leonardo da Vinci which depicts the female subject's smile as blurry, ambiguous and up to the imagination, one moment the smile seems to be there the next it's gone. ${ }^{9}$ Diva: A glamorous and successful female performer or personality as defined in the MerriamWebster online dictionary. Retrieved from https://www.merriam-webster.com/dictionary/diva.
} 
conservative, but encourages women to be bold, and assertive adding that women should embrace sexuality and use their sex as a source of power (p. 72).

\section{Body Language}

This category was further divided into five subcategories, Courteous (woman is not flaunting her body in a sexual way), Dominant (image of woman depicts power or authority), Submissive (woman is portrayed as a wife or mother or does not appear confident), Sexual (majority of skin is shown or the body language implies sex) and Other (a pose that does not fit in the above categories).

Table 2. Frequency and Percentages of Body Language Subcategories per Newspaper

\begin{tabular}{|l|c|c|c|c|c|c|}
\hline Subcategory & \multicolumn{2}{|c|}{ News One } & \multicolumn{2}{c|}{ Ebony } & \multicolumn{2}{c|}{ The Mirror } \\
\hline & Freq. & $\%$ & Freq. & $\%$ & Freq. & $\%$ \\
\hline Courteous & 5 & 8.93 & 0 & 0.00 & 19 & 33.93 \\
\hline Dominant & 9 & 16.07 & 2 & 3.57 & 12 & 21.43 \\
\hline Submissive & 1 & 1.79 & 0 & 0.00 & 17 & 30.36 \\
\hline Sexual & 41 & 73.21 & 53 & 94.64 & 8 & 14.29 \\
\hline Other & 0 & 0.00 & 1 & 1.79 & 0 & 0.00 \\
\hline Total & $\mathbf{5 6}$ & $\mathbf{1 0 0 . 0 0}$ & $\mathbf{5 6}$ & $\mathbf{1 0 0 . 0 0}$ & $\mathbf{5 6}$ & $\mathbf{1 0 0 . 0 0}$ \\
\hline
\end{tabular}

Source: Sampled newspapers, 2018.

Responses from Table 2 indicate that $33.93 \%$ of the images sampled in The Mirror portrayed the body language of women as courteous, with Newsone recording $8.93 \%$ under the same subcategory; it is significant to note that Ebony did not have a single issue coded as courteous. Under the Dominant subcategory The Mirror led with $21.43 \%$ followed by Newsone with $16.07 \%$ and Ebony 3.57\%. The Mirror again led with 30.36\% under Submissive with Newsone returning $1.79 \%$ and Ebony again not having a single issue coded. However, the trend changed under the Sexual subcategory where the portrayal of women in a sexual body pose was found to be a reoccurring subject in both the Ebony (94.64\%) and Newsone (73.21\%) newspapers. These findings are consistent with previous findings by Cronn-Mills (2009), Blaha (2009), Ranchod (2007), Lindner (2004) that the print media portray women in sexually explicit ways, pointing "to the stereotype of the seductress, whereby her power lies in her ability to seduce or entice readers" (Ranchod, 2007, p. 46).

\section{Percentage of Coverage}

The percentage of the coverage category was divided into Full Page (woman's image is more than $50 \%$ of the whole cover page), Half Page (when the woman's image covers at least $50 \%$ of the page) Quarter Page (woman's image covers $25 \%$ of the page) Less than Quarter Page (woman's image covers less than $25 \%$ of the page). 
Table 3. Frequency and Percentages of Percent of Coverage Subcategories

\begin{tabular}{|l|c|c|c|c|c|c|c|c|}
\hline Subcategory & \multicolumn{2}{|c|}{ News One } & \multicolumn{2}{|c|}{ Ebony } & \multicolumn{2}{c|}{ The Mirror } & \multicolumn{2}{c|}{ Total } \\
\hline & Freq. & $\%$ & Freq. & $\%$ & Freq. & $\%$ & Freq. & $\%$ \\
\hline Full Page & 39 & 69.64 & 55 & 98.21 & 28 & 50.00 & 122 & 72.62 \\
\hline Half Page & 12 & 21.43 & 1 & 1.79 & 21 & 37.50 & 34 & 20.24 \\
\hline Quarter Page & 5 & 8.93 & 0 & 0.00 & 7 & 12.50 & 12 & 7.14 \\
\hline Less than Quarter Page & 0 & 0.00 & 0 & 0.00 & 0 & 0.00 & 0 & 0.00 \\
\hline Total & $\mathbf{5 6}$ & $\mathbf{1 0 0 . 0 0}$ & $\mathbf{5 6}$ & $\mathbf{1 0 0 . 0 0}$ & $\mathbf{5 6}$ & $\mathbf{1 0 0 . 0 0}$ & $\mathbf{1 6 8}$ & $\mathbf{1 0 0 . 0 0}$ \\
\hline
\end{tabular}

Source: Sampled newspapers, 2018

Table 3 shows that the Ebony newspaper displayed a lot more of full page images $(98.21 \%)$ than the other newspapers. Newsone also recorded $69.64 \%$ full page images whereas The Mirror had 50\%. For half page images The Mirror had $37.50 \%$, Newsone $21.43 \%$ and Ebony 1.79\%. The Mirror returned $12.50 \%$ of quarter page images against $8.93 \%$ by Newsone. None of the newspapers portrayed images of women less than quarter page.

The findings from Figure 2, point that 122 issues of the total newspapers sampled representing $72.62 \%$ carried full page images of women, alluding to Quainoo's (2011) submission that newspapers use women on their cover pages to entice readership because of the perception that women are more likely to attract readers.

Figure 2. Total Frequency of Percent of Coverage Subcategories

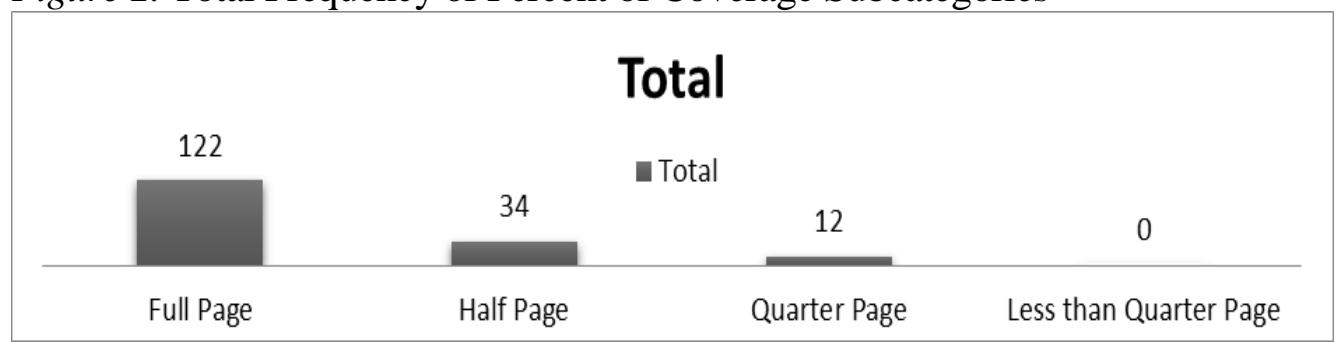

Source: Sampled newspapers, 2018.

\section{Camera Angle}

According to Ranchod (2007), portraying a woman's face underlines her distinctive characteristics and that a faceless woman displays no personality. This category looks at the various angles from which the images of women are portrayed in the newspapers. The category is divided into 90 degrees (woman is looking right into the camera), 45 degrees (woman's face is showing sideways) Away from camera (woman's gaze is away from the camera) and Gaze Not Visible (woman's gaze is not visible). 
Table 4. Frequency and Percentages of Camera Angle Subcategories per Newspaper

\begin{tabular}{|l|c|c|c|c|c|c|c|c|}
\hline Subcategory & \multicolumn{2}{|c|}{ News One } & \multicolumn{2}{c|}{ Ebony } & \multicolumn{2}{c|}{ The Mirror } & \multicolumn{2}{c|}{ Total } \\
\hline & Freq. & $\%$ & Freq. & $\%$ & Freq. & $\%$ & Freq. & $\%$ \\
\hline $90^{\circ}$ & 22 & 39.29 & 32 & 57.14 & 35 & 62.50 & 89 & 52.97 \\
\hline $45^{\circ}$ & 27 & 48.21 & 24 & 42.86 & 21 & 37.50 & 72 & 42.86 \\
\hline Away from camera & 5 & 8.93 & 0 & 0.00 & 0 & 0.00 & 5 & 2.98 \\
\hline Gaze Not Visible & 2 & 3.57 & 0 & 0.00 & 0 & 0.00 & 2 & 1.19 \\
\hline Total & $\mathbf{5 6}$ & $\mathbf{1 0 0 . 0 0}$ & $\mathbf{5 6}$ & $\mathbf{1 0 0 . 0 0}$ & $\mathbf{5 6}$ & $\mathbf{1 0 0 . 0 0}$ & $\mathbf{1 6 8}$ & $\mathbf{1 0 0 . 0 0}$ \\
\hline
\end{tabular}

Source: Sampled newspapers, 2018.

Responses from Table 4 indicate that $62.50 \%$ of images from The Mirror portrayed woman at an angle of 90 degrees, with Ebony and Newsone returning $57.14 \%$ and $39.29 \%$ respectively. Under the 45 degrees subcategory Newsone had $48.21 \%$ followed by Ebony with $42.86 \%$ and The Mirror with $37.50 \%$.

Figure 3. Total Frequency of Camera Angle Subcategories

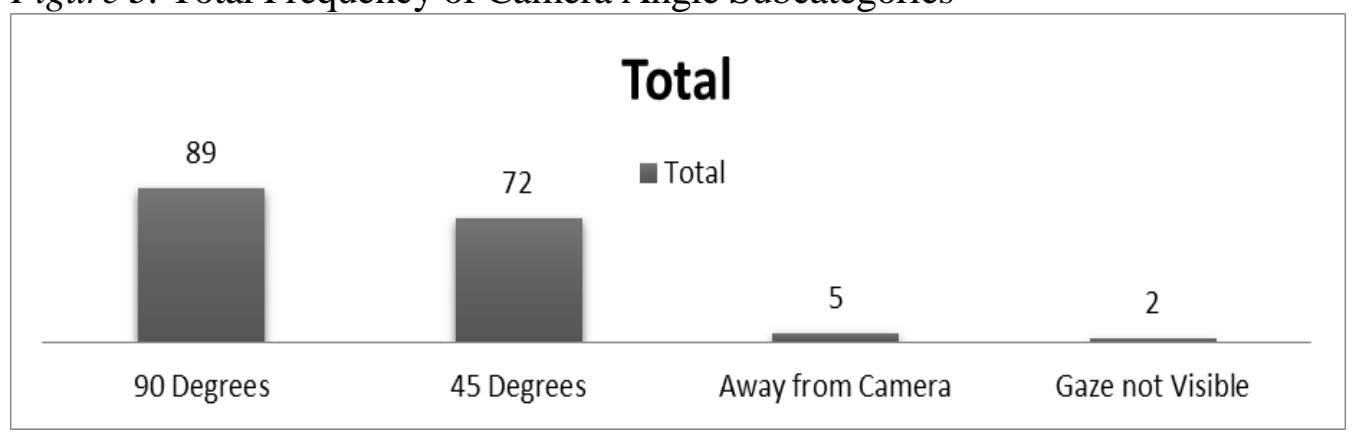

Source: Sampled newspapers, 2018.

Previous studies by Goffman (1978), Kang (1997), and Lindner (2004) touch on the issue of Licensed Withdrawal or far-off gaze, which they define as an instance where the woman is depicted as dissociating herself mentally from the situation at large or is portrayed psychologically drifting from the physical scene by withdrawing her gaze from the scene at large. Findings from this study however indicate that in total $52.97 \%$ had a direct gaze with only $2.98 \%$ of the total images sampled gazing away from the camera. The high return on 90 degrees gaze into camera as evidenced in Figure 3, suggests that the media, guided by their seemingly profit oriented philosophy establish direct eye contact between the reader and the subject, to build and sustain an intimate relationship between the two causing the former to continually want to purchase and possess the latter.

\section{Type of Clothing}

The category was divided into subcategories such as Casual (clothing suitable for an informal occasion), Formal (clothing suitable for an official occasion), Lingerie (underwear, nightgown, bathrobe or bikini), Traditional (Ghanaian or African clothing) and Other (does not fit the above categories). 
Table 5. Frequency and Percentages of Type of Clothing Subcategories

\begin{tabular}{|l|c|c|c|c|c|c|c|c|}
\hline Subcategory & \multicolumn{2}{|c|}{ News One } & \multicolumn{2}{c|}{ Ebony } & \multicolumn{2}{c|}{ The Mirror } & \multicolumn{2}{c|}{ Total } \\
\hline & Freq. & $\%$ & Freq. & $\%$ & Freq. & $\%$ & Freq. & $\%$ \\
\hline Casual & 5 & 8.93 & 2 & 3.57 & 3 & 5.35 & 10 & 5.95 \\
\hline Formal & 4 & 7.14 & 0 & 0 & 15 & 26.79 & 19 & 11.31 \\
\hline Lingerie & 36 & 64.29 & 48 & 85.71 & 0 & 0 & 84 & 50.00 \\
\hline Traditional & 8 & 14.29 & 0 & 0 & 38 & 67.86 & 46 & 27.38 \\
\hline Other & 3 & 5.36 & 6 & 10.71 & 0 & 0 & 9 & 5.36 \\
\hline Total & $\mathbf{5 6}$ & $\mathbf{1 0 0 . 0 0}$ & $\mathbf{5 6}$ & $\mathbf{1 0 0 . 0 0}$ & $\mathbf{5 6}$ & $\mathbf{1 0 0 . 0 0}$ & $\mathbf{1 6 8}$ & $\mathbf{1 0 0 . 0 0}$ \\
\hline
\end{tabular}

Source: Sampled newspapers, 2018

Data from Table 5 show that Ebony (85.71\%) and Newsone (64.29\%) tend to portray women mostly in lingerie whereas The Mirror did not have a single image portrayed in lingerie. The Mirror however returned a high score of $67.86 \%$ under the Traditional subcategory as against $14.29 \%$ by Newsone and $0 \%$ by Ebony. The Mirror again led with $26.79 \%$ under the Formal subcategory where Newsone scored $7.14 \%$ with Ebony again returning 0\%. These finding imply that though The Mirror newspaper as a policy uses women on its front pages to entice readership as mentioned by Quainoo (2011), they are cautious about the clothing the women are presented in.

\section{Degree of Clothing}

This category examines the amount of clothing worn by the women portrayed on the front pages of the various newspapers. This category was divided further into four sub-categories Nude (woman with no clothing on), Semi Nude (woman dressed with very little clothing), Fully Dressed (woman whose dress covers most of her sensitive parts) and Other (image does not fit the above categories).

Table 6. Frequency and Percentages of Degree of Clothing Subcategories per Newspaper

\begin{tabular}{|l|c|c|c|c|c|c|c|c|}
\hline Subcategory & \multicolumn{2}{|c|}{ News One } & \multicolumn{2}{c|}{ Ebony } & \multicolumn{2}{c|}{ The Mirror } & \multicolumn{2}{c|}{ Total } \\
\hline & Freq. & $\%$ & Freq. & $\%$ & Freq. & $\%$ & Freq. & $\%$ \\
\hline Nude & 6 & 10.72 & 11 & 19.64 & 0 & 0.00 & 17 & 10.12 \\
\hline Semi Nude & 33 & 58.93 & 45 & 80.36 & 0 & 0.00 & 78 & 46.43 \\
\hline Fully Dressed & 17 & 30.36 & 0 & 0.00 & 56 & 100 & 73 & 43.45 \\
\hline Other & 0 & 0.00 & 0 & 0.00 & 0 & 0.00 & 0 & 0.00 \\
\hline Total & $\mathbf{5 6}$ & $\mathbf{1 0 0 . 0 0}$ & $\mathbf{5 6}$ & $\mathbf{1 0 0 . 0 0}$ & $\mathbf{5 6}$ & $\mathbf{1 0 0 . 0 0}$ & $\mathbf{1 6 8}$ & $\mathbf{1 0 0 . 0 0}$ \\
\hline
\end{tabular}

Source: Sampled newspapers, 2018.

News One had 6 issues (10.72\%) coded as Nude and 33 issues (58.93\%) coded as Semi Nude, Ebony also had 11 issues (19.64\%) and 45 issues (80.36\%) coded as Semi Nude, The Mirror however indicated a score of $56(100 \%)$ as Fully Dressed suggesting the state owned media was more conscious in the portrayal of female sexuality by way of clothing (Table 6). 


\section{Body Part Shown}

Body Part Shown as shown in Table 7 was coded as a follow up to Degree of Clothing and was divided under the following subcategories breast/cleavage, buttocks, genitals, legs (thighs and calves) and midsection (between chest and waist).

Table 7. Frequency and Percentages of Body Parts shown per Newspaper

\begin{tabular}{|l|c|c|c|c|c|c|}
\hline Subcategory & \multicolumn{2}{|c|}{ News One } & \multicolumn{2}{c|}{ Ebony } & \multicolumn{2}{c|}{ The Mirror } \\
\hline & Freq. & $\%$ & Freq. & $\%$ & Freq. & $\%$ \\
\hline Breast/Cleavage & 47 & 83.93 & 49 & 87.50 & 0 & 0.00 \\
\hline Buttocks & 25 & 44.64 & 44 & 78.57 & 0 & 0.00 \\
\hline Genitals & 0 & 0.00 & 0 & 0.00 & 0 & 0.00 \\
\hline Legs & 32 & 57.14 & 15 & 26.79 & 0 & 0.00 \\
\hline Midsection & 37 & 66.07 & 47 & 83.93 & 0 & 0.00 \\
\hline
\end{tabular}

Source: Sampled newspapers, 2018

According to Table 7 the Ebony and Newsone newspapers display a lot of sensitive body parts with Ebony displaying a lot of Breast/Cleavage $(87.50 \%)$ followed by Newsone $(83.93 \%)$. Under the Buttocks subcategory Ebony returned $78.57 \%$ whereas Newsone had $44.64 \%$. Newsone had 57.14 images of women under the Legs subcategory as against $26.79 \%$ for Ebony. Under the Midsection subcategory Ebony had $83.93 \%$ while Newsone had 66.07\%. The Mirror newspaper again showed that the media can display attractive images of women on the front pages without necessarily exposing their naked bodies; none of the samples coded revealed sensitive parts of the women in this category.

\section{How do Women Relate to the Images of Women as Portrayed by the Print Media?}

\section{Audience Readership}

Table 8. Percentage of Readership

\begin{tabular}{|l|c|c|c|c|}
\hline & Yes & Frequency & No & Frequency \\
\hline News One & $95 \%$ & 57 & $5 \%$ & 3 \\
\hline Ebony & $65 \%$ & 36 & $35 \%$ & 24 \\
\hline The Mirror & $80 \%$ & 48 & $20 \%$ & 12 \\
\hline
\end{tabular}

Source: Sampled newspapers, 2018.

All respondents indicated their awareness of the existence of the three newspapers selected for the study. However in terms of readership the Newsone newspaper seemed to be the most popular with 95\% (Table 8) of the respondents indicating they read it, followed by The Mirror newspaper $80 \%$ and the Ebony newspaper $65 \%$. It is important to note that all three newspapers had a readership of more than $50 \%$ an indication that respondents were familiar with the selected newspapers. 


\section{Newspapers and Stereotyping of Women}

This question was aimed at finding out if respondents per their experiences with the three newspapers felt the media stereotyped women.

Table 9. Frequency and Percentages Newspaper Stereotyping of Women in Society

\begin{tabular}{|l|c|c|}
\hline & Frequency & Percentage \\
\hline Yes & 57 & 85 \\
\hline No & 3 & 15 \\
\hline Total & $\mathbf{6 0}$ & $\mathbf{1 0 0}$ \\
\hline
\end{tabular}

Source: Sampled newspapers, 2018.

As illustrated in Table 9, 85\% of respondents answered positively to the question, suggesting that women are stereotyped by the newspapers, one of the respondents in expressing her opinion on the portrayal of women in the newspapers noted "These newspapers treat women mainly as sex objects; I find the portrayal of women in the newspapers to be offensive". Such responses evoke sentiments as expressed by Iyengar (1991) that the media have what it takes to set the agenda for people to think and talk about specific issues. People often use what is fed them by the media as reference points to decide what is and what is not, the outcome in most cases end up underpinning stereotypes.

\section{How do you think Women are Portrayed Stereotypically?}

This served as a follow up question for respondents who answered yes to the previous section they had the option of ticking more than one answer under this category.

Table 10. Frequencies and Percentages on How Women Are Stereotyped

\begin{tabular}{|l|c|c|}
\hline Stereotype & Frequency & Percentage \\
\hline Sex Objects & 51 & 85.00 \\
\hline Dependent & 0 & 0.00 \\
\hline Homemakers & 20 & 33.33 \\
\hline Submissive & 2 & 3.33 \\
\hline Assertive & 57 & 95.00 \\
\hline Independent & 57 & 95.00 \\
\hline
\end{tabular}

Source: Sampled newspapers, 2018.

As shown in Table 10, 85\% of the respondents cited women as being constructed as Sex Objects. Another 33.33\% noted that the media stereotyped women as Homemakers while $3.33 \%$ of respondents saw the media's construction of women as Submissive. This supports Stump's (2010) contention that when women are not under-represented or invisible, they are often represented in the media in traditional roles such as mothers or sexual objects. However $95 \%$ of respondents defined women as assertive and independent respectively.

In as much as respondents seem to contradict their stance by suggesting high levels of both positive and negative stereotypes it falls in line with Zimmerman 
and Dahlberg's (2008) view that the approaches of today's women toward media depiction of women can be directly linked with Third wave feminism which encourages contemporary women not to be deterred by the sexual objectification found in today's media but rather exercise their "girl power" and make their decisions impartially of how women may be portrayed by the media (p. 73).

\section{Audience Perception of the 21st Century Ghanaian Woman in Relation to the Front Pages of Newsone, Ebony and The Mirror Newspapers}

This open-ended question was meant to further find out women's perception of women as portrayed by the print media. Respondents were asked to list five ways in which they perceived women based on how they (women) were represented by the media. It must be noted that in this instance respondents were given two randomly picked samples of each newspaper to serve as a guide, unlike the coders, respondents were not limited by any predefined themes. The most recurring responses are presented in Table 11.

Table 11. Frequency and Percentages of Audience Perception of Women in Relation to Front Pages of Sampled Newspapers

\begin{tabular}{|l|c|c|}
\hline Audience Perception & Frequency & Percentage \\
\hline Sexy & 60 & 100.00 \\
\hline Mothers & 41 & 68.33 \\
\hline Wives & 44 & 73.33 \\
\hline Beautiful & 47 & 78.33 \\
\hline Professionals & 57 & 95.00 \\
\hline
\end{tabular}

Source: Sampled newspapers, 2018.

All of the respondents described Ghanaian women as sexy, $68.33 \%$ described them as mothers, $73.33 \%$ labeled them as wives while $78.33 \%$ saw them as beautiful, reechoing Stump's (2010) statement that "these sexist stereotypes in the media perpetuate a simplistic, immutable and caricatured image of women... legitimising everyday sexism and discriminatory practices and establishing a barrier to gender equality" (p. 1) and further giving credence to Mensa-Bonsu's (1992) finding that women's political and economic roles are overshadowed by their socially defined roles. The results suggest that in the view of women the print media continue to portray them in ways as found by previous studies of a similar nature (Goffman, 1978; Kang, 1997; Lindner, 2004; Baker, 2005, as cited in Ranchod, 2007, p. 43) which point to the view that stereotypical images of women still exist in the print media and that the ideologies of both patriarchy and capitalism continue to work together in supporting the pervasiveness of negative, disempowering portrayals of women.

It is encouraging however to note that $95 \%$ of respondents saw women as professionals, which supports Quainoo's (2011) contention that 21st century women have traversed the traditionally stereotyped frontier of being branded in the domestic sphere to the professional arena causing their representation and expectations to change. 


\section{Social Perception of Newspaper Portrayal of the 21st Century Ghanaian Woman (Realistic or Unrealistic)}

This question aimed at finding from respondents if media portrayal of women as suggested in a previous section was realistic or unrealistic.

Table 12. Frequency and Percentages of Respondent's Perception on how the Media Portray 21st Century Ghanaian Women (realistic or unrealistic)

\begin{tabular}{|l|c|c|}
\hline Opinion & Frequency & Percentage \\
\hline Realistic & 12 & 20 \\
\hline Unrealistic & 48 & 80 \\
\hline Not Sure & 0 & 0 \\
\hline Total & $\mathbf{6 0}$ & $\mathbf{1 0 0}$ \\
\hline
\end{tabular}

Source: Sampled newspapers, 2018.

Twenty percent of respondents, as reflected in Table 12, believed the newspapers portrayal of women was realistic arguing that since the women had decided out of their own free will to present themselves in public as seen on the front pages of the newspapers, the media could not be accused of stereotyping them.

On the other hand, $80 \%$ of the respondents argued that the media do not present a true reflection of today's Ghanaian women but only present them in such ways that would enhance the sale of their newspapers. This goes to support Carpenter and Edison's (2005) finding that the media creates and sustains unrealistic images and stereotypes of women (as cited in Cronn-Mills, 2009, p. 2) which according to Cronn-Mills (2009) is a media strategy of persuasion.

\section{The Rational for the Portrayal of Women in the Newspapers}

\section{Themes from Interviewing Editors}

The transcribed interviews generated the following themes: Organisational policy, the law and ethics, Public Perception, Stereotype, Sex sells and the 21st century Ghanaian women.

\section{Organisational Policy}

The Editor of The Mirror mentions that:

"The paper still goes by the policy of using pretty women on its cover pages to entice readership and sales. That is why in the event of featuring a man on our front page we add his spouse or a female relation".

The response supports Cronn-Mills' (2009) claim that the media know the techniques and tactics to use as a form of persuasion. 


\section{The Law and Ethics}

The interviews revealed that both editors were aware of the law how far they could go in portraying images of women within the confines of the law.

"The Mirror is a national paper; the constitution enjoins us to operate in that sense. So we are guided by the ethics of the profession". The editor's remark explains the low ranking of The Mirror newspaper in the portrayal of female sexuality as shown in Table 2.

On the other hand the editor of the private owned Newsone states that:

"I'll continue to write about sex as long as I do that within the confines of the law...once what I am doing is not against the law and I am not exposing their nudity or I am not exposing pictures they took in their private homes I don't see anything wrong with it".

The standpoint of the editor of Newsone reflects a position drawn from the guarantee of press "freedom and independence" and the protection from "censorship" as guaranteed under article 162 (1) and (2) of the 1992 Constitution, granted the media respect the fundamental human rights and freedoms of others as guaranteed under Chapter 5 of the Constitution (Article 165).

\section{Public Perception}

In addressing public perception that his paper portrays nude and seminude images of women on its front pages the editor of Newsone responded:

"There are different types of newspapers, others focus on talking about corporate women who are dressed in a three piece suit and skirt, I write about social stories and entertainment and my entertainers do not dress that way, these people are not sex objects as people see them, they are professional models who are trained to dress the way they dress for a specific purpose and a specific agenda that is the way I see all these things people talk about".

The response implies that the newspaper operates within the sociocultural world of entertainment where the exposure of the female body is regarded as normal.

\section{Stereotype}

According to Treise et al. (1994) the media industry continue to stereotype women with a major area of worry being the representation of the female gender as sex objects and the repeated use of their sex to sell products. To this the editor of The Mirror newspaper responds:

"No, no, no, The Mirror does not set out to stereotype women what the paper tries to do is to demystify that notion that women are to be kept in the background and be treated as homemakers and so on". 
On the other hand the editor of Newsone suggests a position of not seeing the sexual portrayal of women as a means of stereotyping them negatively but rather representing them as professional women.

"What the rest of the world has not realized is that I am advertising todays women who are professional models, through that advertising agencies see them and they gain more contracts... are we saying that that category of today's professional women should not be portrayed? Should not be exposed? Should not be encouraged?"

Thwaites, Davis and Mules (1995, p. 152) note that such repeated sexual exposures end up endorsing certain social values as inevitable and natural, and certain beliefs and myths about social identities and cultural norms causing them to become entrenched and take on an authority which eludes the pressure of change.

\section{Sex Sells}

According to the The Women's Manifesto for Ghana the fundamental concept of profitability can be pointed to as a factor in the continued misrepresentation of women.

In responding to this question the editor of Newsone stated:

"Why not, sex is one of the things I wouldn't describe as a soporific subject it excites me it excites you, anything that excites society sells just like soccer, just like politics, if I go and write about orchestra or Beethoven who buys it? ...So yes sex sells, am happy it sells, it puts food on my table".

The editor of The Mirror newspaper also adds that:

Yes, sex sells, but I wouldn't say we project women as sex objects for sale. The basic principle behind the industry is to sell, it is a kind of double edged sword.

The responses in line with Ranchod (2007, p. 21) reveal that the media continue to be "governed by capitalist ideology" and that "through the use of female imagery depicting sexual availability, women's bodies are exploited".

\section{The 21st Century Professional Ghanaian Woman}

Chopra's (2008) study found the print media, in respect of the 21st century woman, guilty of sexism, distortion of image of women and propagation of sex stereotypes. To this end the editor of the Newsone newspaper mentioned that:

"My paper covers a very heterogeneous audience it doesn't just refer to the woman who stays somewhere downtown Sodom and Gomorrah ${ }^{10}$ whose means of livelihood is to be a commercial head potter it also covers the young lady who's just graduated

\footnotetext{
${ }^{10}$ A slam area in Accra the capital of Ghana, notorious for crime, drug peddling and prostitution.
} 
from Med [Medical] school and she works in a private clinic on the Trassaco ${ }^{11}$. So it depends on which aspect of society you are looking at, there are very professional women who have the balls of men today who are excelling from Creative Arts, to Medicine, to Politics to whatever, we also have women who are still basically relying on men for their survival. If a story is about a professional woman who is doing well we put it there as it is, if the story is about a sex worker we put it there as it is, if the story is about a professional model who has to showcase her body in a bikini for whatever professional reason she wants we put it there as it is".

This relates to Bainbridge's (1996) claim (as cited in Thurm, 2001) that the "in thing" for today's media is to project the strength of the female portrayed, mentioning that even though the media continue to parade outstandingly beautiful girls they are presented as strong women willing to take their destiny into their own hands. The editor of The Mirror also adds to Bainbridge's assertion by mentioning that:

"Today's professional woman can be found everywhere from Makola to Parliament...The Mirror makes a conscious effort to fish out for newsmakers and achievers to serve as role models to the youth especially to the young girls".

Such a claim tends to support the cause of the Women's Manifesto of Ghana, which according to Zaney (2012), has since 2004 been used by several Ghanaian and African women's right groups to advocate for social change and increase in women's presence in public life as a means to strengthen democracy and to make policy-making processes more representative of wider sections of the population.

\section{Conclusion}

The study suggests that in spite of the changing roles of women in today's society, newspapers using themes such as pose, facial expression and clothing, still portray women as sex objects for sale. The study, based on responses by the editors suggests that the media is likely to continue using of the female body as a tool for selling news. Women add that though the representations strengthen social construct, they refuse to see themselves as such.

The study calls for a combined conscious effort from government, regulatory bodies, the media and society to experience a meaningful change.

Future researchers should focus on analysing images of women from other media sources such as television or the internet, so as to present a broader picture of the representation of Ghanaian women in the media.

Furthermore, studies could be directed to a comparative study of private and state owned media portrayal of women. It is important to note that all three newspapers portrayed stereotyped images of women. However sex role depictions especially with regard to portraying women as sexy seductresses were portrayed more frequently by the two private owned newspapers.

\footnotetext{
${ }^{11}$ One of Accra's high society residential areas.
} 
Finally, future studies could be done to widen the scope by attempting a cross cultural study of female respondents from tertiary institutions or even a comparative study between female students of a public and a private university to help establish the stand of women on such portrayals.

\section{References}

Asamoah, G. (1980). The Overage of Women in Three Ghanaian Newspapers. Daily Graphic, Ghanaian Times and The Mirror (Unpublished work).

Blaha, E. (2009, November 1). The Portrayal of Women in Magazine Advertisements across Four Different Women's Magazines. Retrieved from www.kon.org.

Chopra, A. (2008, March 17). Portrayal of Women in Print Media. New Delih, Delih, India. Retrieved from http://www.responsenet.org>.

Cronn-Mills, D. (2009). Sex Sells: A Content Analysis of Women in Magazine Advertisement. Minnesota State University, Mankato.

Enu-Kwesi, F. (2006). Social Research in Policy Formulation. Centre for Development.

Gallagher, M. (n.d.). The Image Reflected by Mass Media: Stereotypes, Images of Women in the Mass Media. The Open University, United Kingdom. International Commission for the Study of Communication Problems, UNESCO.

Given, L. M. (2008). The Sage Encyclopedia of Qualitative Research Methods, Vol. 1 and 2. Ed. K. Saumure. University of Alberta, USA: Sage Publications.

Goffman, E. (1978). Gender Advertisements. Cambridge, MA: Harvard University Press.

Hammond, F. E. (1999). Portrayal of Women in the Press: A Content Analysis of The Mirror of 1994 and 1997. School of Communication Studies, University of Ghana, Legon.

Iyengar, S. (1991). Is Anyone Responsible? How Television Frames Political Issues. Chicago: University of Chicago Press.

Johnson, R. B., \& Christensen, L. B. (2008). Educational Research: Quantitative, Qualitative, and Mixed Approaches (3rd ed.). Thousand Oaks, CA: Sage Publications.

Jooste, C. (2007). An Analysis of the Representation of Female Athletes in selected South African Print Media from February 2006 to June 2006. Faculty of Arts at the Nelson Mandela Metropolitan University.

Kang M. E. (1997). The Portrayal of Women's Images in Magazine Advertisements: Goffman's Gender Analysis Revisited. Sex Roles, 37, 979-996.

Kimani, R. W. (2009). Does Gender Matter? A Content Analysis of the Coverage of Ghanaian Politicians by the Daily Graphic. (Master's Thesis). University of Ghana, School of Communication Studies, Legon.

Lindlof, T. R., \& Taylor, B. C. (2002). Qualitative Communication Research Methods. Thousand Oaks, Calif: Sage Publications.

Lindner, K. (2004). Images of Women in General Interest and Fashion Magazine Advertisements from 1955 to 2002. Sex Roles, 51, 390-421.

Mensa-Bonsu, F. (1992). Images of Inequality in the Media: A case Study of the Portrayal of Women in the Weekly Spectator in 1974 and 1986 (Unpublished work).

Neuendorf, K. A. (2002). The Content Analysis Guidebook. Thousand Oaks, CA: Sage Publications.

Nwagbara G. U. (2006). Cultural Stereotypes in Nigerian Print Media Advertisements. Global Journal of Humanities, 5(1\&2), 21-25. 
Obenewaa, N. A. (November 7, 2007). 21Century Ghanaian Feminism: Upstaging Male Domination. Retrieved from http://www.ghanaweb.com/GhanaHomePage/News Archive/.

Olorunpomi, G. (2011, September 27). Newspapers Should Not Publish Nude Images, Lawyers Say. Next. Retrieved from https://bit.ly/2ThVb58.

Pawlowski, I. P. (2007). Sex in Women's Magazine Advertising: An Analysis of the Degree of Sexuality in Women's Magazine Advertising across Age Demographics and Women's Responses. (Unpublished Master's Thesis). University of Canterbury

Paynter, K. C. (October, 2011). Gender Stereotypes and Representation of Female Characters in Children's Picture Books. School of Education, Liberty University. Retrieved from, http://digitalcommons.liberty.edu/cgi/viewcontent.

Pedersen, P. M. (2002). Examining Equity in Newspaper Photographs: A Content Analysis of the Print Media Photographic Coverage of Interscholastic Athletics. International Review for the Sociology of Sport 37(3-4), 303-318.

Potter, W. J. (1985). Gender Representation in Elite Newspapers. Journalism Quarterly, 62(3), 636-640.

Quainoo, K. J. (2011). The Use of Women on the Front Pages of The Mirror: How Effective in Attracting Readership? School of Communication Studies, University of Ghana, Legon.

Ranchod, A. (2007). An Investigation into the Representation of Women in South African Cosmopolitan Magazine Advertisements of 2004. Nelson Mandela Metropolitan University, School of Language, Media and Culture.

Riffe, D., Lacy, S., \& Fico, F. G. (1998). Analyzing Media Messages: Using quantitative content analysis in research. Mahwah, N.J.: Lawrence Erlbaum.

Stump, D. (2010). Combating Sexist Stereotypes in the Media. Committee on Equal Opportunities for Women and Men. Doc. 12267, Report 1, Parliamentary Assembly, Switzerland, Socialist Group. Retrieved from http//assembly.coe.int.

The Women's Manifesto for Ghana. (2004). The Coalition on the Women's Manifesto for Ghana ABANTU for Development. Retrieved from http://library.fes.de/pdffiles/bueros/ghana/02983.pdf.

Thurm, N. J. (2001). The Portrayal of Women in Advertising: Reflection or Creation of Values? Women in Advertising Research Project Paper. Introduction to Graduate Studies and Research. Retrieved from http://www.angelfire.com/ electronic2/nichole_thurm/images/Women\%20in\%2Advertising\%20\%20Researc h\%20Project\%Paper.pdf

Thwaites, T., Davis, L., \& Mules, W. (1995). Tools for Cultural Studies. Palgrave, Macmillan.

Treise, D., Weigold, M. F., Conna, J., \& Garrison, H. (1994). Ethics in Advertising: Ideological Correlations of Consumer Perceptions. Journal of Advertising, 23(3), 61.

Tsegah, M. (2009). The Portrayal of Women in Televison Advertisment: A Study of Ghana Television and TV3 from January to December 2007 (Unpublished Master's Thesis). University of Ghana, School of Communication Studies, Legon.

Zaney G. D. (2012). The Portrayal of Women in the Print Media: A Study of The Mirror in 1975, 1985 and 1995. Retrieved from http://www.ghana.gov.gh/index.php/news/ general-news/16011-8th-anniversary-of-womens-manifesto-marked.

Zimmerman, A., \& Dahlberg, J. (2008). The Sexual Objectification of Women in Advertising: A Contemporary Cultural Perspective. Journal of Advertising Research, 48(1), 72.

Zwennes, S. (1996). The Portrayal of Women in the Print Media: A Study of The Mirror in 1975, 1985 and 1995. School of Communication Studies, University of Ghana, Legon. 